\title{
Thrombophilia, polymorphisms, and vascular disease
}

T C F Sykes, C Fegan, D Mosquera

Academic Vascular Unit, Birmingham Heartlands Hospital, Bordesley Green East, Birmingham B9 5SS, UK

T C F Sykes

D Mosquera

Department of Haematology, Birmingham

Heartlands Hospital C Fegan

Correspondence to: Dr Sykes

Accepted for publication 13 June 2000

Table 1 Prothrombotic gene polymorphisms

\begin{tabular}{ll}
\hline Prothrombotic gene & Polymorphism \\
\hline Factor V Leiden & G1691A \\
Factor V HR2 haplotype & 1299His/Arg and 1736Met/Val \\
Prothrombin & G20210A \\
Methyltetrahydrofolate reductase (MTHFR) & C677T \\
Factor VII & G10976A, -323 0/10, -402 G/A, -401G/T, HVR4 \\
Glycoprotein IIb & HPA-3 \\
Glycoprotein IIIa & PLA1/PLA2 \\
Glycoprotein Ia & 807C/T and 873G/A \\
Glycoprotein Ib-IX-V & Gp 1ba: A, B, C, D, and HPA-2 \\
Plasminogen activator inhibitor 1 & 4G/5G, (CA)n, HindIII \\
Fibrinogen & BclI, G455A, $\alpha$ 313T/A \\
Thrombomodulin & A455V, Ala25Thr \\
Factor XIII & Val34Leu \\
\hline
\end{tabular}
tendency towards thrombosis through enhanced coagulation. Traditionally, it has comprised several rare inherited abnormalities, often leading to thrombosis at a young age. Inherited deficiencies of factors associated with anticoagulation including antithrombin, protein $\mathrm{C}$, and protein $\mathrm{S}$ were the first to be associated with increased thrombosis, in particular venous thrombosis. The discovery of activated protein $\mathrm{C}$ (APC) resistance and the subsequent factor $\mathrm{V}$ Leiden gene polymorphism responsible for $90 \%$ of cases has led to a much broader search for other prothrombotic gene polymorphisms (table 1). The recent evidence concerning the impact of gene polymorphisms on

\begin{abstract}
Thrombophilia traditionally refers to rare inherited defects leading to enhanced coagulation, especially of the venous system. In recent years, a broader search for genetic polymorphisms of prothrombotic genes has been carried out to determine the relative impact on venous and arterial thrombosis. The bulk of evidence is drawn from numerous, often small, heterogeneous, case control association studies, with a variety of end points (deep venous thrombosis, myocardial infarction, or stroke). The data are often conflicting and inconclusive with only factor $V$ Leiden and prothrombin polymorphisms having clear associations with venous thrombosis. Many of the polymorphisms interact with established cardiovascular risk factors, in particular smoking, to increase greatly the risk of a thrombotic episode. Future studies will need to consider the confounding factors of sample size, race, and clinical end points as well geneenvironment interactions. $(\mathcal{F}$ Clin Pathol: $\mathrm{Mol}$ Pathol 2000;53:300-306)
\end{abstract}

Keywords: thrombophilia; polymorphism; thrombosis; vascular disease

venous and arterial thrombosis will be summarised in this review.

\section{Factor V Leiden}

After the identification of individuals with APC resistance, ${ }^{1}$ analysis of DNA revealed a single point mutation, a guanine to adenine transition at nucleotide position 1691 in the factor $\mathrm{V}$ gene, now known as Factor $\mathrm{V}$ Leiden. ${ }^{2}$ This mutation causes a substitution of arginine by glutamine at position 506, resulting in a failure of APC to recognise a major cleavage site on factor $\mathrm{V}$, which allows prothrombin activation to continue unchecked. This defect is associated with APC resistance in $90 \%$ of cases. The factor V Leiden allele is present in about $4-5 \%$ of the normal white population, but is absent from the indigenous populations of Asia, Africa, America, and Australia. ${ }^{3}$ The main clinical manifestation of the factor $\mathrm{V}$ allele is deep venous thrombosis. ${ }^{4}$ Prospective studies have calculated the relative risk for venous thrombosis to be 2.3 for heterozygotes. ${ }^{6}$

Although a risk factor for venous thrombosis, the data to support a role in arterial thrombosis are less conclusive. A study of 560 men under 70 years of age with myocardial infarction revealed a small increase in risk in carriers of factor $\mathrm{V}$ Leiden (odds ratio (OR), $1.4 ; 95 \%$ confidence interval (CI), 0.8 to 2.2 ). ${ }^{7}$

Thrombophilia can be defined as an increased

This was confirmed in a study of 84 young women (18-44 years old), which demonstrated a higher risk of myocardial infarction in carriers (OR, 2.4; 95\% CI, 1.0 to 5.9), especially smokers (OR, 3.6; 95\% CI, 0.9 to 14.4$).{ }^{8}$ Two other studies, including a large population based study, of over 5000 men and women over 65 years of age with three year follow up, found that factor V Leiden was not a risk factor in 373 cases of myocardial infarction, angina, or stroke ${ }^{5}$ compared with 482 controls. ${ }^{9}{ }^{10}$ In cerebrovascular arterial disease, two studies involving nearly 500 patients have failed to demonstrate any increased risk of stroke in patients with the factor $\mathrm{V}$ allele. ${ }^{11}{ }^{12}$

Three studies have examined the role of factor V Leiden in patients with peripheral vascular disease. ${ }^{13-15}$ The prevalence of factor V Leiden was found to be increased in all three studies in patients with peripheral vascular disease but, when based on APC resistance measurements, the prevalence varied between $11.6 \%$ and $41 \%$ of patients with aortoiliac disease using DNA analysis. A small study from Bristol concluded that factor V Leiden was not an important factor in the outcome of infrainguinal bypass grafting. ${ }^{15}$ However, a larger study by Ouriel et al found that the presence of APC resistance significantly reduced graft patency rates. ${ }^{14}$ 


\section{Factor V HR2 haplotype}

This haplotype was discovered after an investigation to determine other causes of APC resistance and has a prevalence of $8-10 \%$ in Italian, Indian, and Somalian populations. ${ }^{16}$ The haplotype codes for two amino acid substitutions 1299His/Arg and 1736Met/Val and its incidence is raised in patients heterozygous for factor V Leiden. Evidence from a French study of 200 patients indicates that it is associated with an increased risk of venous thrombosis (OR, $1.8 ; 95 \% \mathrm{CI}, 1.1$ to 2.8$).{ }^{17} \mathrm{~A}$ larger Italian study found an increased risk of venous thrombosis when the haplotype coexisted with factor V Leiden (relative risk (RR), $10.9 ; 95 \%$ CI, 2.9 to 40.6 ) compared with factor V Leiden on its own (RR, 4.2; CI, 1.6 to 11.3). ${ }^{18}$ However, there was no augmentation of risk when the haplotype was combined with antithrombin, protein $\mathrm{C}$, and protein $\mathrm{S}$ deficiencies. $^{18}$

\section{Prothrombin}

A single nucleotide change of glutamine to arginine was identified at position 20210 by Poort et al in 1996. ${ }^{19}$ The presence of the abnormal gene is associated with an increase in prothrombin values. The prevalence of the mutation is between $1 \%$ and $4 \%$ in the general European population ${ }^{20}$ and $5.5 \%$ in the UK, ${ }^{21}$ but it is rare in Asians or Africans. The evidence suggests that carriers of the mutation have between a three and fivefold increased risk of venous thrombosis. ${ }^{19} 22$

A small study of 79 young women (18-44 years old) with myocardial infarction and 381 controls by Rosendaal et al has shown an increased risk of myocardial infarction with the polymorphism $^{23}$ (OR, 4.0; 95\% CI, 1.1 to 15.1), especially in combination with other risk factors such as smoking. A similar but smaller effect was seen in a larger study of 560 patients (OR, 1.5; 95\% CI, 0.6 to 3.8). ${ }^{24}$ Other studies have failed to confirm this finding, including one investigating a large cohort of 15000 men followed up for 10 years, where over 800 cases of myocardial infarction, stroke, and venous thrombosis were identified. ${ }^{202526}$ There has been no evidence of an association with stroke. ${ }^{11}$

\section{Factor VII gene polymorphism}

Factor VII is a vitamin $\mathrm{K}$ dependent coagulation factor that is converted into activated factor VII by thrombin and factor Xa. Plasma FVII coagulation activity (VIIc) has been shown by some authors to be an independent risk factor for myocardial infarction, ${ }^{27}{ }^{28}$ but others have failed to demonstrate an association. $^{29}{ }^{30} \mathrm{~A}$ single gene on chromosome 13 encodes factor VII. Five polymorphisms have been identified, including an insertion of a decanucleotide at position 323 and a substitution of arginine at position 353 by glutamine (R353Q), the latter associated with $20-25 \%$ lower concentrations of this protein in plasma. The other three polymorphisms include two promoter polymorphisms at positions 401 (G to $\mathrm{T}$ ) and 402 ( $\mathrm{G}$ to $\mathrm{A}$ ) and a common polymorphism at the hypervariable region 4 of intron 7 .

The relation of these polymorphisms to thrombosis is uncertain. A large, case control study with 560 cases and 644 controls revealed that patients with the 353 arginine allele had a lower risk of myocardial infarction compared with patients with the glutamine allele (OR, $0.8 ; 95 \% \mathrm{CI}, 0.6$ to 1.06$)$. In this study, the arginine allele was associated with increased plasma factor VII values. ${ }^{31}$ Other case control studies, including a study of 453 patients with myocardial infarction and 476 controls, found that although the Arg353Gln polymorphism was related to concentrations of factor VII there was no difference in the genotype frequency between patients and controls. ${ }^{30}$ In contrast, one small Italian study of 165 patients with familial myocardial infarction and 225 controls has shown a higher risk of myocardial infarction with the 353 glutamine allele with an associated increase in factor VIIc values. ${ }^{32}$ The hypervariable region polymorphism was also associated with an increased risk of myocardial infarction in this study. ${ }^{32}$ A study of 317 patients with thrombotic stroke and 198 age matched controls provided no evidence of a link between factor VII polymorphisms and stroke. ${ }^{33}$ Similarly, there has been no link with deep venous thrombosis. ${ }^{34}$

\section{Fibrinogen}

Raised fibrinogen concentrations have been shown to be an independent risk factor for myocardial infarction, peripheral vascular disease, and stroke. ${ }^{27}{ }^{28}{ }^{35}$ Fibrinogen is composed of three chains, namely $\alpha, \beta$, and $\gamma$ chains, encoded by different genes clustered on the long arm of chromosome 4. Several polymorphisms have been identified, including the BclI polymorphism and the $455 \mathrm{G} / \mathrm{A}$ polymorphism in the promoter region of the $\beta$ chain and an $\alpha$ chain 313T/A polymorphism. In a large general population study of over 9000 men and women, the $455 \mathrm{~A}$ allele was associated with an increased fibrinogen concentration. ${ }^{36}{ }^{37}$ Unfortunately, the relation between the fibrinogen polymorphisms and thrombosis is less clear. In a study of 102 patients with a family history of myocardial infarction before the age of 65 years and 173 controls, the BclI polymorphism was associated with an increased risk of myocardial infarction (OR, 2.4; 95\% CI, 1.2 to 4.6$){ }^{38}$ However, no link between the BclI polymorphism and myocardial infarction was found in the larger ECTIM study involving 565 patients with myocardial infarction and 668 controls. ${ }^{39}$ Similarly, the $455 \mathrm{G} / \mathrm{A}$ polymorphism has not been linked with myocardial infarction, despite an association between phenotype and fibrinogen values, ${ }^{40}$ although it has been linked with ischaemic stroke in a study of Japanese men and women. ${ }^{41}$ The $\alpha$ chain $313 \mathrm{~T} / \mathrm{A}$ polymorphism was investigated in a study of 585 patients and 658 controls but it was also concluded there was no association between the polymorphism and risk of myocardial infarction. $^{42}$ 


\section{Methyltetrahydrofolate reductase (MTHFR)}

Frosst et al, in 1995, described a common mutation (C677T) of the MTHFR gene. ${ }^{43}$ A cytidine residue at position 677 of the gene is replaced by thymidine. This results in the substitution of an alanine residue by valine, rendering the enzyme both thermolabile and less active. Raised concentrations of homocysteine have been linked with the homozygous genotype but have only been demonstrated when plasma folate values are low. ${ }^{44}$ There are inconclusive data regarding the association of the MTHFR mutation with venous thrombosis. Three studies failed to demonstrate an increased risk with deep venous thrombosis, ${ }^{43}{ }^{45}{ }^{46}$ whereas others found that the homozygous MTHFR genotype is an independent risk factor for venous thrombosis. ${ }^{47} 48$ In addition, numerous studies investigating a link between the MTHFR polymorphism and arterial thrombosis have been undertaken, particularly with regard to myocardial infarction. Although some studies have shown an association with coronary artery disease, ${ }^{49}{ }^{50}$ most failed to reveal a correlation of genotype with myocardial infarction..$^{51-55}$ Similarly, ischaemic stroke has failed to be consistently linked with the MTHFR polymorphism, despite an association between MTHFR and homocysteine concentrations. ${ }^{56} 57$

\section{Platelet glycoprotein IIb-IIIa polymorphism}

The membrane IIb-IIIa complex is a member of the integrin family and plays a key role in platelet aggregation and activation. The complex is the binding site for fibrinogen and Von Willebrand factor. The genes encoding glycoproteins IIb and IIIa are close to one another on chromosome 17. The polymorphism in glycoprotein (Gp) IIIa is a substitution of proline for leucine at position 33, and is described as the PLA1/A2 alloantigen system. PLA2 is expressed on platelets in $24-28 \%$ of white individuals, with about $2 \%$ being homozygous for the alloantigen. ${ }^{58}$ The glycoprotein IIb gene polymorphism consists of a substitution of serine for isoleucine at position 843 (HPA-3a/3b). In 1996, Weiss et al demonstrated that the PLA2 polymorphism of Gp IIIa was associated with a twofold increase in the risk of coronary ischaemia in a small group of 71 patients with myocardial infarction or unstable angina and 68 controls. $^{59}$ In the larger ECTIM study of 620 patients with myocardial infarction and 700 controls, and a study by Ridker et al of 374 patients with myocardial infarction and 704 controls, there was no correlation between the PLA2 allele and myocardial infarction. ${ }^{60}{ }^{61}$ This was confirmed by Gardemann et al in a study of 1191 patients with myocardial infarction. ${ }^{62}$ However, subgroup analysis of patients less than 47 years of age by Carter et al revealed an increase in the PLA2 allele in patients with myocardial infarction (OR, 2.3; 95\% CI, 1.01 to 5.22$){ }^{63} \mathrm{~A}$ study of 200 young patients $(<45$ years old) with myocardial infarction also confirmed an association with the PLA2 allele (OR, $1.84 ; 95 \%$ CI, 1.12 to 3.03$).{ }^{64} \mathrm{An}$ increased risk of coronary stent thrombosis was found to be associated with PLA2 (OR, 5.26; $95 \%$ CI, 1.55 to 17.8$).{ }^{65}$ However, a larger case control study, with 1000 patients in each group, failed to demonstrate a link between the polymorphism and complications, including stent thrombosis, after coronary catheter interventions. ${ }^{66}$ There is no evidence to suggest a link with stroke. ${ }^{606768}$

Little information is available about the clinical relevance of the Gp IIb polymorphism HPA-3, although there was no link between the polymorphism and stent thrombosis at 30 day follow up. ${ }^{69}$ No association between the HPA-3 polymorphism and stroke has been found. ${ }^{67}$

\section{Platelet glycoprotein Ia-IIa polymorphism}

After the interest in glycoprotein IIIa polymorphisms, the Ia-IIa gene complex was investigated, with the identification of two silent polymorphisms on the $\mathrm{Gp}$ Ia gene, at positions 807C/T and 873G/A. These polymorphisms affect platelet receptor density. ${ }^{70}$ Individuals homozygous for the $807 \mathrm{C} / 873 \mathrm{G}$ allele have low receptor densities, whereas individuals homozygous for the $807 \mathrm{~T} / 873 \mathrm{~A}$ allele have high receptor densities, enhancing platelet binding to collagen. There are significant differences in the distribution of the Gp Ia C807T alleles among different racial groups. ${ }^{71}$

A case control study of 177 patients with myocardial infarction and 89 controls found an increased risk of myocardial infarction with the homozygous 807T/873A genotype (OR, 3.3; $95 \% \mathrm{CI}, 1.2$ to 8.8$).{ }^{72}$ An association of the $807 \mathrm{~T}$ allele with non-fatal myocardial infarction in a group of 223 patients $(<49$ years of age) has also been reported (OR, 2. 61;95\% CI, 1.26 to 5.41$).^{70}$ In contrast, a case control study of 546 patients and 507 controls less than 75 years old failed to link the $807 \mathrm{~T} / 873 \mathrm{~A}$ alleles with myocardial infarction. ${ }^{73}$ In a case control study of 45 patients less than 50 years old, the $807 \mathrm{~T}$ allele was found to be associated with stroke (OR, 3.02; 95\% CI, 1.20 to 7.61$).{ }^{74}$ No association was found between the $807 \mathrm{~T} / 873 \mathrm{~A}$ allele and venous thrombosis in a study involving 331 white patients.

\section{Platelet glycoprotein 1b-IX-V polymorphism}

This complex is a combination of four glycoprotein chains: Gp 1b $\alpha$, Gp $1 b \beta$, Gp IX, and Gp V. Two polymorphisms worthy of note include a polymorphism of $\mathrm{Gp} 1 \mathrm{~b} \alpha$ with four polymorphic forms $\mathrm{A}, \mathrm{B}, \mathrm{C}, \mathrm{D}$, and a $\mathrm{C}$ to $\mathrm{T}$ change at position 3550, resulting in a Thr145Met substitution, the latter part of the HPA-2 alloantigen system. In a case control study of over 100 patients in each group, both the $\mathrm{C} / \mathrm{B}$ genotype and the HPA-2 polymorphism were associated with an increased risk of myocardial infarction (OR, 2.84; 95\% CI, 1.28 to 6.41 ) and stroke (OR, 2.83; 95\% CI, 1.16 to $7.07),{ }^{75}$ but not with venous thrombosis. ${ }^{75}$ The HPA-2 alloantigen is not associated with an increased risk of stroke. ${ }^{67}$ 
Plasminogen activator inhibitor 1 (PAI-1) gene polymorphism

Plasminogen activator inhibitor 1 inhibits tissue plasminogen, increased concentrations of which have been shown to be independently associated with myocardial infarction. ${ }^{76} \mathrm{~A}$ single gene on the long arm of chromosome 7 encodes PAI-1. Three polymorphic sites have been described including a single nucleotide insertion/deletion $(4 \mathrm{G} / 5 \mathrm{G})$ of the promoter region, a 3' HindIII site, and a CA dinucleotide repeat in intron 3 . The $4 \mathrm{G} / 5 \mathrm{G}$ polymorphism has been linked with plasma concentrations of PAI- $1 .^{77}$ The $4 \mathrm{G}$ allele is associated with significantly higher concentrations of PAI-1 than the $5 \mathrm{G}$ allele, especially in the presence of raised triglyceride values. ${ }^{79}$ The $4 \mathrm{G}$ allele has been linked to an increased risk of myocardial infarction in a small group of young Swedish men. ${ }^{80}$ This finding was supported by a study of 453 patients in which 166 patients had a history of myocardial infarction (OR, 2.0; 95\% CI, 1.1 to 3.7$).^{81}$ However, other studies including one of 1353 white patients undergoing coronary angiography ${ }^{82}$ have failed to reveal an association of the $4 \mathrm{G}$ allele with myocardial infarction. ${ }^{77} 8384$ Similarly, case control studies of 150 patients with venous thrombosis and 558 patients with stroke showed no association with the $4 \mathrm{G}$ allele. ${ }^{85} 86$

\section{Thrombomodulin}

Thrombomodulin is an endothelial cell receptor that transforms the procoagulant thrombin into an anticoagulant with an increased ability to activate protein C. Several gene polymorphisms have been identified, including a $\mathrm{C} / \mathrm{T}$ change coding Ala455Val and a $\mathrm{G}$ to A mutation at position 127 leading to an Ala25Thr substitution. A study of 97 Swedish patients with premature myocardial infarction revealed an over-representation of the allele encoding Ala455, suggesting that it is a risk factor for myocardial infarction. ${ }^{87}$ However, this was not confirmed in a study by Ireland et al of 104 patients. ${ }^{88}$ A further study of 560 men and matched controls has linked an increased risk of first myocardial infarction, especially in those less than 50 years old, with the Ala25Thr polymorphism (OR, 6.5; 95\% CI, 0.8 to 54.2 ). However, the authors are cautious about the results because the confidence intervals are wide. ${ }^{89}$ There is no evidence suggesting a role in venous thrombosis..$^{90}$

\section{Factor XIII}

A deficiency of factor XIII is associated with severe bleeding, illustrating that its main function is the formation of stable crosslinked fibrin. Several polymorphisms have been described, especially of the A subunit, in which theVal34Leu polymorphism has been the most extensively investigated. A case control study of 221 patients and 254 controls revealed a protective effect of the Val/Leu genotype against venous thrombosis. ${ }^{91} \mathrm{~A}$ further study of 189 patients and 187 controls did not confirm this protective effect but did demonstrate a protective effect of the homozygous Leu genotype. ${ }^{92}$ The evidence for a role in arterial thrombosis comes from a case control study of patients with myocardial infarction where the Leu genotype appeared to have a protective effect, being the least common genotype in patients with a history of myocardial infarction. ${ }^{93}$ This finding has been confirmed in a recent Finnish case control study of young survivors of myocardial infarction. ${ }^{94}$ A study of 529 patients and 436 age matched controls with cerebral infarction showed there was no evidence of a protective effect linked to the Leu34 genotype. ${ }^{95}$

\section{Synergy}

Although individual polymorphisms might have little or no independent effect on venous or arterial thrombosis, they might act in synergy with other genetic risk factors or established cardiovascular risk factors. The incidence of venous thrombosis increases when factor V Leiden is combined with protein C, ${ }^{96}$ protein $\mathrm{S},{ }^{97}$ or antithrombin III deficiency. ${ }^{98} \mathrm{~A}$ combination of factor V Leiden and hyperhomocysteinaemia or MTHFR carries with it an increased risk of venous thrombosis. ${ }^{6}{ }^{48}$ Factor $\mathrm{V}$ Leiden combined with prothrombin increases the risk of recurrent deep venous thrombosis. ${ }^{99} 100$ The risk of arterial thrombosis, such as myocardial infarction, is not increased in the presence of the factor V Leiden and prothrombin polymorphisms, ${ }^{101}$ or when the PAI-1 (4G/5G), PLA1/PLA2, Gp 1b, factor VII Arg355Gln, factor V Leiden, MTHFR, and prothrombin polymorphisms are combined. ${ }^{64}$ However, when factor V Leiden and prothrombin polymorphisms including MTHFR are examined in conjunction with known cardiovascular risk factors such as hypertension, hypercholesterolaemia, diabetes, and especially smoking, the risks increase up to 25 fold (OR, 24.7; 95\% CI, 7.17 to 84.9). ${ }^{101}$ Similar results have been found in a group of 560 men and controls where the thrombomodulin ${ }^{89}$ Ala25Thr polymorphism is associated with an increased risk of myocardial infarction and interacts with smoking (OR, 8.8; $95 \% \mathrm{CI}, 1.8$ to 42.2 ) and metabolic risk factors (OR, 4.4; 95\% CI, 0.9 to 21.3 ). Other studies of young women ${ }^{102}$ with either the factor $\mathrm{V}$ or prothrombin polymorphism have also revealed myocardial infarction risks that are amplified in smokers. This augmentation of risk with smoking also occurred with the PLA1/A2 polymorphism in a group of 200 patients with myocardial infarction (OR, 13.7; 95\% CI, 6.41 to 31.2) compared with non-smoking carriers (OR, $1.84 ; 95 \% \mathrm{CI}, 1.12$ to 3.03$).^{64}$

\section{Conclusion}

Many of the reviewed studies provide conflicting data concerning the clinical importance of gene polymorphisms. This is in part the result of specific problems that arise with case control association studies where the study sets out to test whether a genetic marker occurs more frequently in cases than in controls. In particular, several confounding factors arise making direct comparisons between studies difficult. These include a variation in the definition of cases and controls (selection bias), the heterogeneous 
way the disease process is manifest (for example, myocardial infarction and stroke), and the differences that occur between ethnic groups. The complex pathogenesis of thrombosis means that a single gene defect might exert only a small effect and therefore studies with large numbers of patients are required before any conclusion can be drawn. In addition, the impact of a given polymorphism will be dependent on gene-environment interactions that might be specific for a given cohort of patients. Despite the limitations of the reviewed studies, a striking feature in many is the interaction of polymorphisms with known cardiovascular risk factors, especially smoking, which leads to a dramatic rise in the risk of thrombosis. The evidence to date implicates factor V Leiden and prothrombin G20210A as risk factors for venous thrombosis, especially in combination with other risk factors; however, the association with arterial thrombosis is much weaker. The remaining polymorphisms cannot be linked clearly to either venous or arterial thrombosis because of the inconsistencies in the results of the studies currently available. Future studies will need to deal with the problem of confounding factors and focus on gene-environment interactions to appreciate fully the impact of a given polymorphism in venous and arterial thrombosis.

1 Dahlback B, Carlsson M, Svensson PJ. Familial thrombophilia due to a previously unrecognized mechanism characterized by poor anticoagulant response to activated protein C: prediction of a cofactor to activated protein C [see comments]. Proc Natl Acad Sci U S A 1993;90:1004-

$$
8 .
$$

Zoller B, Dahlback B. Linkage between inherited resistance to activated protein $\mathrm{C}$ and factor $\mathrm{V}$ gene mutation in venous thrombosis [see comments]. Lancet 1994;343: $1536-8$.

3 Zivelin A, Griffin JH, Xu X, et al. A single genetic origin for a common Caucasian risk factor for venous thrombosis. Blood 1997;89:397-402.

4 Koster T, Rosendaal FR, de Ronde H, et al. Venous thrombosis due to poor anticoagulant response to activated protein C: Leiden thrombophilia study [see comments]. Lancet 1993;342:1503-6.

5 Ridker PM, Vaughan DE. Hemostatic factors and the risk of myocardial infarction [letter; comment]. $N$ Engl f Med 1995;333:389-90.

6 Ridker PM, Hennekens CH, Selhub J, et al. Interrelation of hyperhomocyst(e)inemia, factor $\mathrm{V}$ Leiden, and risk of future venous thromboembolism [see comments]. Circulation 1997;95:1777-82.

7 Doggen CJ, Cats VM, Bertina RM, et al. Interaction of coagulation defects and cardiovascular risk factors: increased risk of myocardial infarction associated with factor $\mathrm{V}$ Leiden or prothrombin 20210A [see comments]. Circulation 1998;97:1037-41

8 Rosendaal FR, Siscovick DS, Schwartz SM, et al. Factor V Leiden (resistance to activated protein $\mathrm{C}$ ) increases the risk of myocardial infarction in young women [see comments] Blood 1997;89:2817-21.

9 Cushman M, Rosendaal FR, Psaty BM, et al. Factor V Leiden is not a risk factor for arterial vascular disease in the elderly: results from the cardiovascular health study. Thromb Haemost 1998;79:912-15.

10 Ardissino D, Peyvandi F, Merlini PA, et al. Factor V (Arg $506 \rightarrow \mathrm{Gln}$ ) mutation in young survivors of myocardial $506 \rightarrow$ Gln) mutation in young survivors
infarction. Thromb Haemost 1996;75:701-2.

11 Longstreth WT, Jr, Rosendaal FR, Siscovick DS, et al. Risk of stroke in young women and two prothrombotic mutations: factor V Leiden and prothrombin gene varian (G20210A). Stroke 1998;29:577-80.

12 Catto A, Carter A, Ireland $\mathrm{H}$, et al. Factor V Leiden gene mutation and thrombin generation in relation to the development of acute stroke. Arterioscler Thromb Vasc Biol 1995 15:783-5.

13 Sampram ES, Lindblad B, Dahlback B. Activated protein C resistance in patients with peripheral vascular disease. $\mathcal{F}$ Vasc Surg 1998;28:624-9.

14 Ouriel K, Green RM, DeWeese JA, et al. Activated protein C resistance: prevalence and implications in peripheral vascular disease. F Vasc Surg 1996;23:46-51.

15 Foley PW, Irvine CD, Standen GR, et al. Activated protein $\mathrm{C}$ resistance, factor V Leiden and peripheral vascular disease. Cardiovasc Surg 1997;5:157-60.
16 Bernardi F, Faioni EM, Castoldi E, et al. A factor V genetic component differing from factor V R506Q contributes to the activated protein $\mathrm{C}$ resistance phenotype. Blood

17 Alhenc-Gelas M, Nicaud V, Gandrille S, et al. The factor V gene A4070G mutation and the risk of venous thrombosis. Thromb Haemost 1999;81:193-7.

18 Faioni EM, Franchi F, Bucciarelli P, et al. Coinheritance of the HR2 haplotype in the factor $\mathrm{V}$ gene confers an increased risk of venous thromboembolism to carriers of factor V R506Q (factor V Leiden). Blood 1999;94:3062-6.

19 Poort SR, Rosendaal FR, Reitsma PH, et al. A common genetic variation in the 3'-untranslated region of the
prothrombin gene is associated with elevated plasma prothrombin levels and an increase in venous thrombosis. Blood 1996;88:3698-703.

20 Rosendaal FR, Doggen CJ, Zivelin A, et al. Geographic distribution of the $20210 \mathrm{G}$ to A prothrombin variant. Thromb Haemost 1998; 79:706-8.

21 Cumming AM, Keeney S, Salden A, et al. The prothrombin gene G20210A variant: prevalence in a UK anticoagulant clinic population. Br F Haematol 1997;98:353-5.

22 Hillarp A, Zoller B, Svensson PJ, et al. The 20210 A allele of the prothrombin gene is a common risk factor among Swedish outpatients with verified deep venous thrombosis [see comments]. Thromb Haemost 1997;78:990-2.

23 Rosendaal FR, Siscovick DS, Schwartz SM, et al. A common prothrombin variant ( $20210 \mathrm{G}$ to $\mathrm{A}$ ) increases the risk of myocardial infarction in young women. Blood 1997; 90:1747-50.

24 Doggen CJ, Cats VM, Bertina RM, et al. Interaction of coagulation defects and cardiovascular risk factors: increased risk of myocardial infarction associated with factor $\mathrm{V}$ Leiden or prothrombin 20210A [see comments]. Circulation 1998;97:1037-41.

25 Ferraresi P, Marchetti G, Legnani C, et al. The heterozygous $20210 \mathrm{G} / \mathrm{A}$ prothrombin genotype is associated with early venous thrombosis in inherited thrombophilias and is not increased in frequency in artery disease. Arterioscler Thromb Vasc Biol 1997;17:2418-22.

26 Ridker PM, Hennekens CH, Miletich JP. G20210A mutation in prothrombin gene and risk of myocardial infarction, stroke, and venous thrombosis in a large cohort of US men. Circulation 1999;99:999-1004.

27 Meade TW, Mellows S, Brozovic M, et al. Haemostatic function and ischaemic heart disease: principal results of the Northwick Park heart study [see comments]. Lancet 1986;2:533-7.

28 Heinrich J, Balleisen L, Schulte H, et al. Fibrinogen and factor VII in the prediction of coronary risk. Results from the PROCAM study in healthy men [published erratum appears in Arterioscler Thromb 1994;14:1392]. Arterioscler Thromb 1994;14:54-9.

29 Smith FB, Lee AJ, Fowkes FG, et al. Hemostatic factors as predictors of ischemic heart disease and stroke in the Edinburgh artery study. Arterioscler Thromb Vasc Biol 1997;17: 3321-5.

30 Lane A, Green F, Scarabin PY, et al. A Factor VII $\mathrm{Arg} / \mathrm{G} \ln 353$ polymorphism determines factor VII coagulant activity in patients with myocardial infarction (MI) and control subjects in Belfast and in France but is not a strong indicator of MI risk in the ECTIM study. Atherosclerosis 1996;119:119-27.

31 Doggen CJ, Manger CV, Bertina RM, et al. A genetic propensity to high factor VII is not associated with the risk of myocardial infarction in men. Thromb Haemost 1998;80: 281-5.

32 Iacoviello L, Di Castelnuovo A, de Knijff P, et al. Polymorphisms in the coagulation factor VII gene and the risk of myocardial infarction [see comments]. N Engl f Med 1998; 338:79-85.

33 Heywood DM, Carter AM, Catto AJ, et al. Polymorphisms of the factor VII gene and circulating FVII:C levels in relation to acute cerebrovascular disease and poststroke mortality. Stroke 1997;28:816-21

34 Koster T, Rosendaal FR, Reitsma PH, et al. Factor VII and fibrinogen levels as risk factors for venous thrombosis. A case-control study of plasma levels and DNA polymorphisms - the Leiden thrombophilia study (LETS). Thromb Haemost 1994;71:719-22.

35 Wilhelmsen L, Svardsudd K, Korsan-Bengtsen K, et al. Fibrinogen as a risk factor for stroke and myocardial infarction. N Engl f Med 1984;311:501-5.

36 Tybjaerg-Hansen A, Agerholm-Larsen B, Humphries SE, et al. A common mutation $(\mathrm{G}-455 \rightarrow \mathrm{A})$ in the betafibrinogen promoter is an independent predictor of plasma fibrinogen, but not of ischemic heart disease. A study of 9,127 individuals based on the Copenhagen city heart study. F Clin Invest 1997;99:3034-9.

37 Humphries SE, Ye S, Talmud P, et al. European atherosclerosis research study: genotype at the fibrinogen locus (G-455-A beta-gene) is associated with differences in plasma fibrinogen levels in young men and women from different regions in Europe. Evidence for gendergenotype-environment interaction. Arterioscler Thromb Vasc Biol 1995;15:96-104.

38 Zito F, Di Castelnuovo A, Amore C, et al. Bcl I polymorphism in the fibrinogen beta-chain gene is associated with the risk of familial myocardial infarction by increasing plasma fibrinogen levels. A case-control study in a sample of GISSI-2 patients. Arterioscler Thromb Vasc Biol 1997; 17:3489-94.

39 Behague I, Poirier O, Nicaud V, et al. Beta fibrinogen gene polymorphisms are associated with plasma fibrinogen and 
coronary artery disease in patients with myocardial infarction. The ECTIM study. Etude cas-temoins sur l'infarctus du myocarde. Circulation 1996;93:440-9.

40 Gardemann A, Schwartz O, Haberbosch W, et al. Positive association of the beta fibrinogen $\mathrm{H} 1 / \mathrm{H} 2$ gene variation to basal fibrinogen levels and to the increase in fibrinogen concentration during acute phase reaction but not to coronary artery disease and myocardial infarction. Thromb Haemost 1997;77:1120-6.

41 Nishiuma S, Kario K, Yakushijin K, et al. Genetic variation in the promoter region of the beta-fibrinogen gene is associated with ischemic stroke in a Japanese population. Blood Coagul Fibrinolysis 1998;9:373-9.

42 Curran JM, Evans A, Arveiler D, et al. The alpha fibrinogen T/A312 polymorphism in the ECTIM study [letter]. Thromb Haemost 1998;79:1057-8.

43 Frosst $\mathrm{P}$, Blom HJ, Milos R, et al. A candidate genetic risk factor for vascular disease: a common mutation in methylfactor for vascular disease: a common mutation in methyl111-13.

44 Jacques PF, Bostom AG, Williams RR, et al. Relation between folate status, a common mutation in methylenetetrahydrofolate reductase, and plasma homocysteine concentrations [see comments]. Circulation 1996;93:7-9.

45 Brown K, Luddington R, Baglin T. Effect of the MTHFRC677T variant on risk of venous thromboembolism: interaction with factor $\mathrm{V}$ Leiden and prothrombin (F2G20210A) mutations. Br $\mathcal{F}$ Haematol 1998;103:42-4

46 Tosetto A, Missiaglia E, Frezzato M, et al. The VITA project: C677T mutation in the methylenetetrahydrofolate reductase gene and risk of venous thromboembolism. Br f Haematol 1997;97:804-6.

47 Margaglione $M$, D'Andrea G, d'Addedda $M$, et al. The methylenetetrahydrofolate reductase TT677 genotype is associated with venous thrombosis independently of the
coexistence of the FV Leiden and the prothrombin A20210 coexistence of the FV Leiden and the prothrom

48 Cattaneo M. Hyperhomocysteinemia: a risk factor for arterial and venous thrombotic disease. Int $\mathcal{F}$ Clin Lab Res 1997;27:139-44.

49 Kluijtmans LA, Kastelein JJ, Lindemans J, et al. Thermolabile methylenetetrahydrofolate reductase in coronary artery disease. Circulation 1997;96:2573-7.

50 Morita H, Taguchi J, Kurihara H, et al. Genetic polymorphism of 5,10-methylenetetrahydrofolate reductase (MTHFR) as a risk factor for coronary artery disease. Circulation 1997;95:2032-6.

51 Schmitz C, Lindpaintner K, Verhoef P, et al. Genetic polymorphism of methylenetetrahydrofolate reductase and
myocardial infarction. A case-control study. Circulation myocardial infarctio

52 Wilcken DE. MTHFR $677 \mathrm{C} \rightarrow \mathrm{T}$ mutation, folate intake, neural-tube defect, and risk of cardiovascular disease [see comments]. Lancet 1997;350:603-4.

53 Adams M, Smith PD, Martin D, et al. Genetic analysis of thermolabile methylenetetrahydrofolate reductase as a risk factor for myocardial infarction. $Q \mathcal{F} M$ 1996;89:437-44.

$54 \mathrm{Ma}$ J, Stampfer MJ, Christensen B, et al. A polymorphism of the methionine synthase gene: association with plasma folate, vitamin B12, homocyst(e)ine, and colorectal cancer risk [in process citation]. Cancer Epidemiol Biomarkers Preच 1999;8:825-9.

55 Schwartz SM, Siscovick DS, Malinow MR, et al. Myocardial infarction in young women in relation to plasma total homocysteine, folate, and a common variant in the methylenetetrahydrofolate reductase gene. Circulation 1997;96: 412-17.

56 Markus HS, Ali N, Swaminathan R, et al. A common polymorphism in the methylenetetrahydrofolate reductase gene, homocysteine, and ischemic cerebrovascular disease [see comments]. Stroke 1997;28:1739-43.

57 Kostulas K, Crisby M, Huang WX, et al. A methylenetetrahydrofolate reductase gene polymorphism in ischaemic stroke and in carotid artery stenosis. Eur F Clin Invest 1998, 28:285-9.

58 Nurden AT. Platelet glycoprotein IIIa polymorphism and coronary thrombosis [see comments] [review]. Lancet 1997;350:1189-91.

59 Weiss EJ, Bray PF, Tayback M, et al. A polymorphism of a platelet glycoprotein receptor as an inherited risk factor for coronary thrombosis [see comments]. N Engl f Med 1996; 334:1090-4.

60 Ridker PM, Hennekens CH, Schmitz C, et al. PIA1/A2 polymorphism of platelet glycoprotein IIIa and risks of polymorphism of platelet glycoprotein IIIa and risks of myocardial infarction, stroke, and vent

61 Herrmann SM, Poirier O, Marques-Vidal P, et al. The Leu33/Pro polymorphism (P1A1/P1A2) of the glycoprotein IIIa (GPIIIa) receptor is not related to myocardia infarction in the ECTIM study. Etude cas-temoins de l'infarctus du myocarde. Thromb Haemost 1997;77:117981.

62 Gardemann A, Humme J, Stricker J, et al. Association of the platelet glycoprotein IIIa P1A1/A2 gene polymorphism to coronary artery disease but not to nonfatal myocardial infarction in low risk patients. Thromb Haemost 1998;80:214 17.

63 Carter AM, Ossei-Gerning N, Grant PJ. Platelet glycoprotein IIIa PlA polymorphism in young men with myocardial infarction [letter; comment]. Lancet 1996;348:485-6.

64 Ardissino D, Mannucci PM, Merlini PA, et al. Prothrombotic genetic risk factors in young survivors of myocardial infarction. Blood 1999;94:46-51.
65 Walter DH, Schachinger V, Elsner M, et al. Platelet glycoprotein IIIa polymorphisms and risk of coronary stent thrombosis [see comments]. Lancet 1997;350:1217-19.

66 Laule M, Cascorbi I, Stangl V, et al. A1/A2 polymorphism of glycoprotein IIIa and association with excess procedural
risk for coronary catheter interventions: a case-controlled study [see comments]. Lancet 1999;353:708-12.

67 Carlsson LE, Greinacher A, Spitzer C, et al. Polymorphisms of the human platelet antigens HPA-1, HPA-2, HPA-3, and HPA- 5 on the platelet receptors for fibrinogen (GPIIb/ IIIa), von Willebrand factor (GPIb/IX), and collagen (GPIa/IIa) are not correlated with an increased risk for stroke. Stroke 1997;28:1392-5.

68 Wagner KR, Giles WH, Johnson CJ, et al. Platelet glycoprotein receptor IIIa polymorphism P1A2 and ischemic stroke risk: the stroke prevention in young women study. Stroke 1998;29:581-5.

69 Kastrati A, Schomig A, Seyfarth M, et al. P1A polymorphism of platelet glycoprotein IIIa and risk of restenosis after coronary stent placement. Circulation 1999;99:1005-10.

70 Santoso S, Kunicki TJ, Kroll H, et al. Association of the platelet glycoprotein Ia C807T gene polymorphism with nonfatal myocardial infarction in younger patients. Blood 1999;93:2449-53.

71 Dinauer DM, Friedman KD, Hessner MJ. Allelic distribution of the glycoprotein Ia (alpha2-integrin) C807T/ G873A dimorphisms among Caucasian venous thrombosis patients and six racial groups. Br f Haematol 1999;107: 563-5.

72 Moshfegh K, Wuillemin WA, Redondo M, et al. Association of two silent polymorphisms of platelet glycoprotein Ia/IIa receptor with risk of myocardial infarction: a case

73 Croft SA, Hampton KK, Sorrell JA, et al. The GPIa C807T dimorphism associated with platelet collagen receptor density is not a risk factor for myocardial infarction. Br f Haematol 1999;106:771-6.

74 Carlsson LE, Santoso S, Spitzer C, et al. The alpha2 gene coding sequence T807/A873 of the platelet collagen receptor integrin alpha2betal might be a genetic risk factor for the development of stroke in younger patients. Blood 1999; 93:3583-6.

75 Gonzalez-Conejero R, Lozano ML, Rivera J, et al. Polymorphisms of platelet membrane glycoprotein $\mathrm{Ib}$ associated with arterial thrombotic disease. Blood 1998;92:2771-6.

76 Thogersen AM, Jansson JH, Boman K, et al. High plasminogen activator inhibitor and tissue plasminogen activator levels in plasma precede a first acute myocardial infarction in both men and women: evidence for the fibrinolytic system as an independent primary risk factor. Circulation 1998:98:2241-7.

77 Ye S, Green FR, Scarabin PY, et al. The 4G/5G genetic polymorphism in the promoter of the plasminogen activator inhibitor-1 (PAI-1) gene is associated with differences in plasma PAI-1 activity but not with risk of myocardial infarction in the ECTIM study. Etude cas temoins sur l'infarctus du myocarde. Thromb Haemost 1995;74:837-41.

78 Panahloo A, Mohamed-Ali V, Lane A, et al. Determinants of plasminogen activator inhibitor 1 activity in treated
NIDDM and its relation to a polymorphism in the plasminogen activator inhibitor 1 gene. Diabetes 1995;44: $37-42$.

79 Mansfield MW, Stickland MH, Grant PJ. Environmental and genetic factors in relation to elevated circulating levels of plasminogen activator inhibitor-1 in Caucasian patients with non-insulin-dependent diabetes mellitus. Thromb Haemost 1995;74:842-7.

80 Eriksson P, Kallin B, Hooft FM, et al. Allele-specific increase in basal transcription of the plasminogen-activator inhibitor 1 gene is associated with myocardial infarction. Proc Natl Acad Sci U S A 1995;92:1851-5.

81 Ossei-Gerning N, Mansfield MW, Stickland MH, et al. Plasminogen activator inhibitor- 1 promoter $4 \mathrm{G} / 5 \mathrm{G}$ genotype and plasma levels in relation to a history of myocardial infarction in patients characterized by coronary angiography. arction in patients characterized by coronary
Arterioscler Thromb Vasc Biol 1997;17:33-7.

82 Anderson JL, Muhlestein JB, Habashi J, et al. Lack of association of a common polymorphism of the plasminogen activator inhibitor-1 gene with coronary artery disease and myocardial infarction. I Am Coll Cardiol 1999;34: 1778-83.

83 Ridker PM, Hennekens CH, Lindpaintner K, et al. Arterial and venous thrombosis is not associated with the $4 \mathrm{G} / 5 \mathrm{G}$ polymorphism in the promoter of the plasminogen activator inhibitor gene in a large cohort of US men [see comments]. Circulation 1997;95:59-62.

84 Doggen CJ, Bertina RM, Cats VM, et al. The 4G/5G polymorphism in the plasminogen activator inhibitor- 1 gene is not associated with myocardial infarction [in process citation]. Thromb Haemost 1999;82:115-20.

85 Stegnar M, Uhrin P, Peternel P, et al. The $4 \mathrm{G} / 5 \mathrm{G}$ sequence polymorphism in the promoter of plasminogen activator inhibitor-1 (PAI-1) gene: relationship to plasma PAI-1 level in venous thromboembolism. Thromb Haemost 1998;79: 975-9.

86 Catto AJ, Carter AM, Stickland M, et al. Plasminogen activator inhibitor-1 (PAI-1) $4 \mathrm{G} / 5 \mathrm{G}$ promoter polymorphism and levels in subjects with cerebrovascular disease. Thromb Haemost 1997;77:730-4.

87 Norlund L, Holm J, Zoller B, et al. A common thrombomodulin amino acid dimorphism is associated with myocardial infarction. Thromb Haemost 1997;77:248-51. 
88 Ireland H, Kunz G, Kyriakoulis K, et al. Thrombomodulin gene mutations associated with myocardial infarction [see gene mutations associated with myocar

89 Doggen CJ, Kunz G, Rosendaal FR, et al. A mutation in the thrombomodulin gene, $127 \mathrm{G}$ to A coding for Ala25Thr and the risk of myocardial infarction in men. Thromb Haemost 1998;80:743-8.

90 van der Velden PA, Krommenhoek-Van Es T, Allaart CF, al. A frequent thrombomodulin amino acid dimorphism is not associated with thrombophilia. Thromb Haemost 1991;65:511-13.

91 Catto AJ, Kohler HP, Coore J, et al. Association of a common polymorphism in the factor XIII gene with venous thrombosis. Blood 1999;93:906-8.

92 Franco RF, Reitsma PH, Lourenco D, et al. Factor XIII Val34Leu is a genetic factor involved in the etiology of venous thrombosis. Thromb Haemost 1999;81:676-9.

93 Kohler HP, Stickland MH, Ossei-Gerning N, et al. Association of a common polymorphism in the factor XII gene with myocardial infarction. Thromb Haemost 1998;79: g-13.

94 Wartiovaara U, Perola M, Mikkola $\mathrm{H}$, et al. Association of FXIII Val34Leu with decreased risk of myocardial infarction in Finnish males. Atherosclerosis 1999,142.295-300.

95 Catto AJ, Kohler HP, Bannan S, et al. Factor XIII Val 34 Leu: a novel association with primary intracerebral hemorrhage. Stroke 1998;29:813-16.
96 Koeleman BP, Reitsma PH, Allaart CF, et al. Activated protein $\mathrm{C}$ resistance as an additional risk factor for thrombosis in protein C-deficient families. Blood 1994;84:1031-5.

97 Zoller B, Berntsdotter A, Garcia dF, et al. Resistance to activated protein $\mathrm{C}$ as an additional genetic risk factor in hereditary deficiency of protein S. Blood 1995;85:3518-23.

98 van Boven HH, Reitsma PH, Rosendaal FR, et al. Factor V Leiden (FV R506Q) in families with inherited antithrombin deficiency. Thromb Haemost 1996;75:417-21.

99 de S, V, Martinelli I, Mannucci PM, et al. The risk of recurrent deep venous thrombosis among heterozygous carriers of both factor V Leiden and the G20210A prothrombin mutation. N Engl f Med 1999;341:801-6.

100 Salomon O, Steinberg DM, Zivelin A, et al. Single and combined prothrombotic factors in patients with idiopathic venous thromboembolism: prevalence and risk assessment. Arterioscler Thromb Vasc Biol 1999;19:511-18.

101 Inbal A, Freimark D, Modan B, et al. Synergistic effects of prothrombotic polymorphisms and atherogenic factors on the risk of myocardial infarction in young males. Blood 1999; 93:2186-90.

102 Rosendaal FR, Siscovick DS, Schwartz SM, et al. A common prothrombin variant $(20210 \mathrm{G}$ to $\mathrm{A}$ ) increases the risk of myocardial infarction in young women. Blood 1997; 90:1747-50. 